\title{
Latent Dangers in a Patent Pool: The European Commission's Approval of the 3G Wireless Technology Licensing Agreements
}

\author{
Michael R. Franzinger $\dagger$
}

\section{TABLE OF CONTENTS}

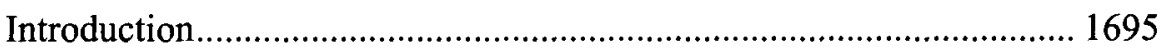

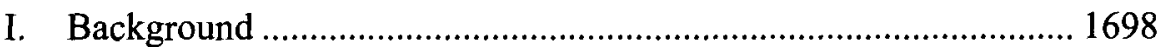

A. The Evolution of Standards in the Wireless Communications

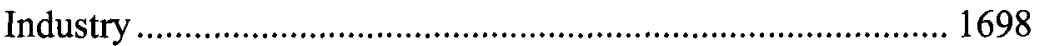

1. The 2G Mobile Telephone Standards............................... 1698

2. The 3G Mobile Communication Standards....................... 1699

B. Europe's Past Efforts at Standardization ............................... 1700

C. Licensing of Essential Patents for 3G Standards .................... 1702

II. The European Commission's Competition Law ......................... 1708

A. Article 8I: The Foundation of European Antitrust Doctrine... 1709

B. New Block Exemptions, Individual Exemptions, and "Comfort Letters" .................................................................. 1710

1. The Technology Transfer Block Exemption ...................... 1711

2. Exceptions Developed in Individual Cases ....................... 1712

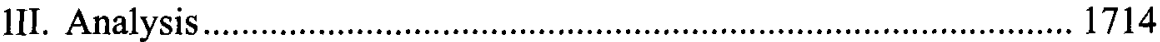

A. The Japanese Fair Trade Commission's Early Clearance of the Platform .................................................................... 1714

Copyright (C) 2003 California Law Review, Inc. California Law Review, Inc. (CLR) is a California nonprofit corporation. CLR and the authors are solely responsible for the content of their publications.

$\dagger \quad$ Associate, Weil, Gotshal \& Manges, LLP; J.D., School of Law, University of California, Berkeley (Boalt Hall), 2002; M.S., University of California, Berkeley, 2002; B.S., Case Western Reserve University, 1998. Beginning in the fall of 2004, I will serve as a judicial clerk to the Honorable Sharon Prost, U.S. Court of Appeals for the Federal Circuit. Thanks are due to Jennifer Conners, Tina Hulse, and all the other CLR members who helped prepare this Comment for publication, as well as to Mark Lemley for advice and editorial comments, Gunnar Wolf for guidance on European competition law, and Brian Kearsey for providing much-needed information. Any opinions expressed or errors committed herein are solely my own. 
B. The European Commission's Conditional Approval of the Platform

1. Features of the Platform That Likely Favored the Commission's Approval................................................. 1717

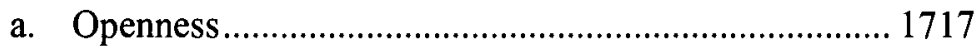

b. Transactional Efficiencies........................................... 1718

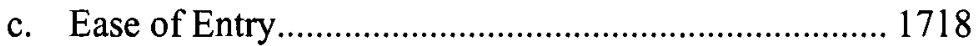

d. Reduction of Prices for Consumers ............................. 1719

e. Horizontal versus Vertical Agreements ...................... 1720

2. The European Commission's Conditions for Approval of the Platform.............................................................. 1720

a. The Requirement of Competition Among the Radio Interfaces.................................................................. 1721

b. Avoiding the Restriction of Competition in Downstream Markets............................................... 1722

c. Avoiding the Facilitation of Price Fixing ................... 1722

d. Ensuring That the Platform Does Not Discourage lnnovation

3. Conclusion: Approval of the Platform Was Justified Under European Community Law

1V. The Remaining Problem of Separate Standard-Setting and Licensing Organizations 1724 


\title{
Latent Dangers in a Patent Pool: The European Commission's Approval of the 3G Wireless Technology Licensing Agreements
}

\author{
Michael R. Franzinger
}

\section{INTRODUCTION}

Throughout the history of the telecommunications industry, intellectual property rights and antitrust law have traded places as dominant legal concerns in the sector. Early on, the patents of Bell and Morse generated some of the most celebrated intellectual property litigation of the nineteenth century.' The conflict was not limited to the United States; in what was perhaps a harbinger of the role of national politics in modern standardsetting bodies, British inventors Cooke and Weatherstone were able to prevent Morse from getting a patent in their country by obtaining a suspiciously broad construction of their own patent. ${ }^{2}$

As telecommunications firms coagulated into national monopolies, antitrust became a more pressing matter. The United States broke up the Bell system, ${ }^{3}$ while European nations struggled to deal with the monopolies left behind when they privatized their national telephone systems. ${ }^{4}$

Now, however, antitrust and intellectual property are increasingly becoming costars in the international telecommunications drama. Telecommunications, by its very nature, involves the linking of devices, and

1. See The Telephone Cases, 126 U.S. 1 (1888) (upholding Bell's claim to be the original inventor of the telephone); American Bell Tel. Co. v. Spencer, 8 F. 509, 511 (C.C.D. Mass. 1881) (construing Bell's patent to cover "all means and processes" of transmitting speech by electrical undulations); O'Reilly v. Morse, 56 U.S. (15 How.) 62 (1853) (holding Morse's telegraph patents valid and infringed).

2. Rudi Bekkers \& Isabelle Liotard, European Standards for Mobile Communications: The Tense Relationship Between Standards and Intellectual Property Rights, 21 EUR. INTELL. Prop. Rev. $110,115(1999)$.

3. United States v. Western Elec. Co., 569 F. Supp. 1057 (D.D.C. 1983) (approving consent decree), aff'd sub nom. California v. United States, 464 U.S. 1013 (1983).

4. See generally Pierre Larouche, Competition Law and Regulation in European Telecommunications, at $\operatorname{xxxv}(2000)$. The European Union completed the process of liberalizing the telecommunications sector on January 1, 1998. Id. 
therefore demands substantial interoperability. ${ }^{5}$ The more widespread the interoperability, the better, so international technical standards are indispensable. Given the high-tech nature of the industry, creating viable standards that do not involve patented inventions is impossible. ${ }^{6}$ Standard setting in such an environment creates opportunities for monopolization of the entire standard-setting body by an owner of intellectual property. ${ }^{7}$ The holder of an intellectual property right, generally a patent, ${ }^{8}$ has a strong incentive to "capture" the standard - that is, to get its patented invention included in the standard and force all users of the standard to license the patent. ${ }^{9}$ Standard-setting organizations have therefore developed a number of defenses against such behavior, such as "reasonable" license-fee requirements ${ }^{10}$ and mandatory disclosure of relevant intellectual property during the standard-selection process. " However, participants continue to search for ways to circumvent these rules and capture the standard. ${ }^{12}$

In light of these concerns, and perhaps dissatisfied with the current ineffectual licensing policies of the standard-setting organizations, developers and manufacturers of so-called Third Generation, or " $3 \mathrm{G}$," mobile communications products have created a patent-pooling agreement dubbed the 3G Patent Platform. This agreement makes standardized licensing

5. "Telecommunications" and the "telecommunications industry," as used hcrein, refer to the means for electronically transmitting information over significant distances, including mobile and land-based telephony and the Internet. "Interoperability" is the ability of different devices to work together. While important in many industries, it is particularly necessary in the telecommunications industry because, among other reasons, users want to be able to communicate with each other even though they usc devices from different manufacturers.

6. The European Union officially acknowledges this reality. Bekkers \& Liotard, supra note 2, at 116.

7. Robert P. Merges et al., Intellectual Property in the New Technological Age 1177 (2d ed. 2000).

8. Occasionally, standards also include copyrighted material. Because copyrighted material included in standards is typically material of a technical nature, such as software, it would probably be subject to a similar antitrust analysis. Trademark rights are usually only peripherally related to standard setting. They may denote, for example, that a product complies with the standard. It would be interesting to consider whether a trade secret could maintain its legal status if disscminated to all the members of a large standard-setting organization.

9. Mark A. Lemley, Antitrust and the Internet Standardization Problem, 28 ConN. L. Rev. 104I, I086-88 (1996).

10. See, e.g., infra text aecompanying notes $45-48$.

11. E.g., In re Dell Computer Corp., 121 F.T.C. 616 (1996).

12. See, e.g., Rambus Inc. v. Infineon Techs. AG, I64 F. Supp. 2d 743 (E.D. Va. 2001) (upholding jury verdict that Rambus committed fraud by conccaling its pending patent applications that related to a semiconductor memory device standard when the standard-sctting organization's understood practice was to require disclosure of such applications), aff'd in part, rev'd in part, and vacated in part, 318 F.3d 1081 (Fed. Cir. 2003) (holding that Rambus only had a duty to disclose applications with claims that actually read on a standard, and not applications with claims that were merely related to the standard); see generally Jason Kipnis, Beating the System: Abuses of the Standards Adoption Proccss, IEEE COMM. MAG., July 2000, at 102 (detailing surrcptitious mcthods that businesses have used to capture standards). 
processes and fees available to all comers. ${ }^{13}$ The agreement exists separately from the organizations that are mapping out the standards for $3 \mathrm{G}$ technology; companies that participate in the standard-setting process are not required to become part of the 3G Patent Platform.

As with any major international intellectual property pool, the antitrust authorities in Japan, Europe, and the United States have been scrutinizing the arrangement. In 2000, Japan was the first to give its formal (but preliminary) approval. ${ }^{14}$ The United States and Europe followed in late $2002 .^{15}$ As these approvals indicate, the agreement had much to commend it, and indeed something like the Platform was probably viewed as an indispensable element of the commercialization of $3 \mathrm{G}$ mobile devices. But, at least in the published material related to their decisions, none of these authorities explicitly considered the damage that could be wrought by moving the licensing obligations outside the governance of the standardsetting organization: a patent owner is free to join the organization while staying out of the patent pool, thus helping to create the standard even while avoiding any commitment to license its patents that the standard incorporates.

One issue that did receive some attention from the antitrust authorities, but was not considered problematic enough to derail the agreement, was the prospect of the agreement stifling innovation in the industry. Buyers of intellectual property could act as a cartel that drives down license fees. Because capping license fees is one of the main purposes of the $3 \mathrm{G}$ Patent Platform, the agreement actually serves the interests of buyers of intellectual property licenses, even though it is technically an agreement among sellers of licenses. Sellers are motivated to sign on to the Platform principally because they are also buyers of licenses; on the other hand, companies that expect to focus significantly on selling licenses have tended to stay away from the $3 \mathrm{G}$ Patent Platform. ${ }^{16}$ The coordinated reduction of license fees by participants in the patent pool will likely diminish the reward for innovation in $3 \mathrm{G}$ technology, at least among those companies that have joined the pool.

13. See infra Part II.B.

14. Japanese Fair Trade Commission, Views on the Consultation Pursuant to Prior Consultation System Relating to Patent and Know-how Licensing Agreement, Dec. 14, 2000, available at http://www.3gpatents.com/news/2000158e.htm (unofficial translation). The preliminary opinion issued in 2000 was made official through the formal approval granted in June 2002. See 3G Patents Ltd., 3G Patent Platform Definition, at http://www.3gpatcnts.com/3gplatform.htm (last updated Feb. 13, 2003).

15. Letter from Charles A. James, Assistant Attorney General, United States Department of Justice, to Ky P. Ewing, Vinson \& Elkins, LLP (Nov. 12, 2002), at http://www.usdoj.gov/atr/public/ busreview/200455.pdf; Press Release, European Commission, Antitrust Clearance for Licensing of Patents for Third Generation Mobile Services (Nov. 12, 2002), available at http://www.3gpatents.com/ news/ec_app.htm [hereinafter European Commission].

16. See Europcan Commission, supra note 15, at 2 (noting that "a number of major $3 \mathrm{G}$ essential patent holders (among those Ericsson, Nokia, Motorola, and Qualcomm) are not party to the [3G Patent Platform] agreements"). 
This Comment considers the effects of the 3G Patent Platform on innovation and competition in the mobile telecommunications industry. Following a deseription in Part I.A and I.B of the relationship of standards and intellectual property in the mobile communications industry, Part I.C presents the novel features of the Platform's licensing structure. Part II provides background information on European competition law, and Part III assesses the legality of the arrangement under that law. Part IV then addresses the practical problems facing the Platform's implementation, with particular emphasis on the issue of nonparticipation by a few major industry players. Part IV further suggests possible changes to the agreement and to regulatory efforts that might improve the effectiveness of the licensing scheme.

\section{I \\ BACKGROUND}

\section{A. The Evolution of Standards in the Wireless Communications Industry}

Technology in the mobile telecommunications industry has developed in a series of "generations." Because of the need for interoperability, the technology tends to progress in coordinated great leaps forward by the industry, rather than through continuous, gradual improvement. This process helps to ensure that small, incremental improvements do not render devices incompatible with each other. The generations are customarily referred to as $2 \mathrm{G}, 3 \mathrm{G}$, et cetera. ${ }^{17}$

\section{The $2 G$ Mobile Telephone Standards}

The wireless communications industry is in the midst of a transition from $2 \mathrm{G}$ to $3 \mathrm{G}$ technology. The $2 \mathrm{G}$ mobile telephones currently dominate the market. ${ }^{18}$ These telephones replaced the first-generation analog communication with digital, enabling higher-quality transmission and the transfer of data as well as voice. ${ }^{19}$ The caller-ID and text messaging functions available on most modern cellular phones represent a direct result of the transition to digital data transfer. ${ }^{20}$

Several transmission standards have arisen under the $2 \mathrm{G}$ banner. For example, CDMA IS-95, also known by the trade name cdmaOne ${ }^{\mathrm{TM}}$, is based on CDMA (Code Division Multiple Access) technology. CDMA

17. There is also a $2.5 \mathrm{G}$, but it is basically a stopgap improvement to $2 \mathrm{G}$ motivated by delays in $3 \mathrm{G}$ commercialization, and is not discussed in any detail here.

18. Too Compelling to Resist: Information Builders Introduces Mobile Technologies, WIRELESSREPORT.NET (Dec. 3, 2002), at http://technologyreports.net/wirelessinnovator/?articlelD= 1365.

19. International Telecommunication Union, All About the Technology, at http://www.itu.int/osg/ spu/ni/3G/technology (last visited Sept. 4, 2003) [hereinafter ITU Guide].

20. Silicon Press, Before $3 G$ Wireless Networks, at http://www.silicon-press.eom/briefs/ brief.before3g (last visited Sept. 4, 2003). 
service is common in the United States. ${ }^{21}$ Another prominent $2 \mathrm{G}$ standard is GSM (Global Standard for Mobile communication), ${ }^{22}$ which is used primarily in Europe and elsewhere. ${ }^{23}$

Three regional organizations took on the role of implementing $2 \mathrm{G}$ standards: the T1 Committee in the United States, the Telecommunications Technology Committee in Japan, and the European Telecommunications Standards Institute (ETS1) in Europe. ${ }^{24}$ ln the case of GSM, the ETSI and the GSM Association oversee the implementation of the standard. ${ }^{25}$ The ETSI functions as a quasi-governmental organization with the power to create essentially mandatory telecommunications standards for Europe. ${ }^{26}$

\section{The $3 G$ Mobile Communication Standards}

$3 \mathrm{G}$ mobile communication devices ${ }^{27}$ are already making inroads into consumer markets. ${ }^{28} 3 \mathrm{G}$ "phones," if they can still be called by such a limiting name, are transforming wireless communications from a mostly voice-based medium to one that offers the full capability, eonvenience, and

21. CNET, Cell Phone Carrier Technology Chart, at http://www.cnet.com/wireless/ 0-1923403-8-7093240-4.html (last visited Dec. 2, 2001) (on file with author).

22. ITU Guide, supra note 19 . Other $2 \mathrm{G}$ standards include

D-AMPS: Digital-Advanced Mobile Phone Service, which is simply a digitized version of the first-generation analog system. searchNetworking.com, D-AMPS, at http://searchnetworking.techtarget.com/sDefinition/0,sid7_gci2 I3876,00.html (Iast updated Apr. 1I, 2003). D-AMPS is also sometimes called TDMA IS-136 (TDMA stands for TimeDivision Multiple Access), but this terminology causes confusion because the GSM standard incorporates TDMA technology. See ITU Guide, supra note I9.

PDC: Personal Digital Cellular. PDC is the leading mobile technology in Japan. Id.

PHS: Personal Handyphone System. PHS is also used in Japan. Id.

23. Id.

24. Bekkers \& Liotard, supra note 2, at 110.

25. European Telecommunications Standards Institute, About ETSI, at http://www.etsi.org/ aboutetsi/home.htm (last visited Sept. 4, 2003).

26. Bekkers \& Liotard, supra note 2, at 114-I5.

27. "Telephones" is too narrow a term for these devices. "3G provides services like Intcrnet connection, transmission of large-scale and moving contents photographed by digital cameras and videos, and software downloading." $3 \mathrm{G}$ Newsroom, Introduction into $3 G$, at http://www.3gnewsroom.com/html/about_3g/intro_3g.shtml (last updated Mar. 21, 2003).

28. South Korean companies SK Telecom and KT Freetel implemented 3G technology in their home market in early 2002. Press Release, 3G, Real 3G Hits the U.S. (Oct. 30, 2002), at http:/www.3g.co.uk/PR/October2002/4323.htm. 3G technology has also been available for some time in Japan, in the form of NTT DoCoMo's FOMA (Freedom of Mobile Multimedia Access) network; handsets for use with the FOMA network include a US $\$ 500$ mobile video phone. Press Release, 3G, The Case for 3G (Oct. 28, 2002), at http:/www.3g.co.uk/PR/October2002/43I I.htm; Jay Wrolstad, Japanese Tech Giants Unveil $3 G$ Wireless Platform, WIRELEss NewsFactor, Feb. 28, 2002, at http://www.wirelessnewsfactor.com/perl/story/16569.html. 3G services were first launched in the United States in January 2002 and went nationwide seven months later. Press Release, 3G, First Commercial 3G Wireless Network Launched in the United States (Jan. 30, 2002), at http://www.3g.co.uk/PR/1689.htm; Press Release, 3G, First Nationwide 3G Network in US Launched (Aug. 9, 2002), at http://www.3g.co.uk/PR/August2002/3882.htm. The British $3 \mathrm{G}$ network came online in March 2003. Press Release, 3G, Where Is My 3G Phone? (Mar. 4, 2003), at http://www.3g.co.uk/PR/March2003/4992.htm. 
speed of present-day land-based Internet service, as well as greatly enhanced voice quality. ${ }^{29} \mathrm{New}$ and forthcoming mobile devices can support videoconferencing, application sharing, and multimedia applications. ${ }^{30} 3 \mathrm{G}$ technology uses Internet Protocol transfer mechanisms, which involve dividing a collection of data into packets for faster and more reliable transfer across a network. ${ }^{31} 3 \mathrm{G}$ service will eventually transfer data at up to $2 \mathrm{Mbps}$ (megabits pcr second), compared to I4.4 Kbps (kilobits per second) with the best of $2 \mathrm{G}$ technology. ${ }^{32}$ Further, $3 \mathrm{G}$ access is "always on": there is no time wasted "connecting" to the Internet. ${ }^{33}$

Much of the technology for $3 \mathrm{G}$ is still awaiting large-scale commercial implementation. ${ }^{34}$ Licensing issues will likely hinder that process. These are not the frequency-licensing issues that received attention several years back when potential $3 \mathrm{G}$ service providers paid governments surprisingly and (in hindsight) unjustifiably high fees for pieces of the electromagnetic broadcasting spectrum. ${ }^{35}$ That controversy is essentially over, but a new kind of licensing issue lurks in licenses to use the intellectual property that goes into making 3G-compatible devices. The latter type of license is the subject of this Comment.

\section{B. Europe's Past Efforts at Standardization}

Europe's telecommunications standard-setting body is the private, nonprofit European Telecommunications Standards Institute (ETSI). ${ }^{36}$ The ETSI describes its role as "developing a wide range of standards and other technical documentation as Europe's contribution to world-wide standardization in telecommunications, broadcasting and information technology."37

The ETSI is subject to more influence from thc public sphere than are most U.S. standard-setting bodies. The European Union, for example, can compel the ETSI to develop a standard for a specific purpose. ${ }^{38}$ Since the ETSI makes some decisions by vote of national representatives, including

29. Introduction into $3 G$, supra note 27.

30. 3G Newsroom, What is 3G?, at www.3gnewsroom.com/html/about_3g/what_is_3g.shtml (last updated Mar. 21, 2003). More exotic applications may include automatie refrigerators that send orders to local grocery stores when items need restocking. Id.

31. Introduction into $3 G$, supra note 27.

32. Id.

33. Id

34. Id. However, the development of $3 \mathrm{G}$ 's sequel, $4 \mathrm{G}$, is already well under way. Move Over 3G: Here Comes 4G, EconomisT, May 31, 2003, at 61 .

35. Pat Regnier, It Ain't Heavy... It's My Debt, TIMEeurope, Apr. 16, 2001, available at http://www.time.com/time/europe/biz/column/0,13716,105687,00.html. The U.K. raised $\$ 32$ billion and Germany raised $\$ 45$ billion auctioning rights to the 3G speetrum, or nearly $\$ 550$ per inhabitant of those two countries. Id.

36. European Telecommunications Standards Institute, supra note 25.

37. Id.

38. Bekkers \& Liotard, supra note 2, at 115. 
delegates from governmental regulatory bodies, the national governments of Europe also possess substantial influence over the organization (influence that they often use to favor industrial powers in their own countries) ${ }^{39}$

Public authorities can also enforce ETSI standards. The European Union can take an ETSI standard and convert it into a regulation, which is then binding on member states. ${ }^{40}$ The standard, and the owners of patents necessary to practice it, could thereby gain a dominant market position. Commentators have pointed out that the European authorities might then institute compulsory licensing of those patents. ${ }^{41}$

Licensing issues arise because sophisticated technological standards such as those promulgated by the ETSI inevitably involve intellectual property. ${ }^{42}$ The term "essential IPR" refers to an intellectual property right that covers some component of a standard, without which it would be technically impossible to conform to that standard. ${ }^{43}$ Because of the often mandatory nature of European telecommunications standards, holders of essential IPRs can demand lieense fees from an entire Europe-wide industry; competitors have no alternative but to practice a standard that has been mandated by the government. IPR holders therefore face tantalizing incentives for capture. ${ }^{44}$

While earlier European standardization bodies had simply developed a custom of reasonable-rate licensing of essential IPRs, the ETSI was the first to attempt to establish an enforcement mechanism that would force members to license reasonably. ${ }^{45}$ The policy, adopted in 1993, required ETSI members to commit to granting "fair, reasonable, and non-exclusive" licenses of essential IPRs to other ETSI members. ${ }^{46}$ If members did not wish to grant such licenses for certain IPRs, they would have to notify the ETSI within 180 days after it published a draft standard.$^{47}$ The punishment for noncompliance was the potential forfeiture of all licenses the offending member had purchased from other members. ${ }^{48}$

Intellectual property owners felt that this policy was too strict. This dissatisfaction arose partly because the policy placed an onerous duty upon them to identify their relevant IPRs very early in the technology development process. ${ }^{49}$ According to the policy, if an IPR owner failed to

39. Id. at 113,115 ; see also id. at 116 (chart) (illustrating the various influences on the ETSI's standard-setting activities).

40. Id at 115 .

41. Id. at 125 .

42. Id at 116 .

43. Id.

44. Id. at 117 .

45. Id at 120 .

46. Id at $12 \mathrm{I}$.

47. Id.

48. Id

49. Id 
realize that the standard implicated its IPRs within the 180-day notification period, it could not opt out of granting licenses to all the members of the standard-setting organization. ${ }^{50}$ In this situation, since ETS1 standards are often made compulsory by the European Union, the IPR owner might be forced to license its rights at a limited royalty rate to every participant in the European telecommunications market. ${ }^{51}$ These intellectual property owners brought their case before the European Commission and found it to be sympathetic. The European Commission directed the ETSI to dilute its policy and require only "a reasonable effort to inform ETSI of IPRs" that might be implicated in the standard. ${ }^{52}$ The new policy also removed all semblance of mandatory character from the licensing policy, merely instructing the director of the ETS1 to "request" licenses from the IPR owner on fair, reasonable, and nondiscriminatory terms. ${ }^{53}$

While this change pacified the participants, it led to numerous licensing problems as the $2 \mathrm{G}$ standards came into use. License fees for $2 \mathrm{G}$ devices were high. ${ }^{54}$ Owners of essential IPRs restricted their licenses as they saw fit. ${ }^{55}$ And major manufacturers may have been kept out of the device market for GSM, the European 2G standard, because of IPR owners' refusal to grant reasonable-rate licenses. ${ }^{56}$

\section{Licensing of Essential Patents for $3 G$ Standards}

Parties interested in developing global technical standards for $3 G$ have formed the Third Generation Partnership Project (3GPP). ${ }^{57}$ The six "Organizational Partners" in 3GPP include ETSI and the United States' Committee $\mathrm{T} 1 .^{58}$ Organizational Partners are defined as groups with "officially recognized status and the capability and authority to define, publish and set standards within the 3GPP scope, in [a] nation or

50. Id.

51. Id.

52. Id.; John Temple Lang, European Community Antitrust Law: Innovation Markets and High Technology Industries, in INT'L ANTITRust Law \& Policy 24 (Barry E. Hawk ed., I996).

53. Bekkers \& Liotard, supra note 2, at 122.

54. Joanne Taaffe, $3 G$ Patents Initiative Devised to Avoid "Qualcomm-type" Disputes, CommunicationsWeek INT'L, June I9, 2000, available at 2000 WL I2764517.

55. See, e.g., Rudi Bekkers et al., Intellectual Property Rights, Strategic Technology Agreements and Market Structure: The Case of GSM (Sept. 2000), at 10, at http://www-edocs.unimaas.nI/ files/mer00030.pdf ("In the early 1990s, ... the IPRs problem peaked when Motorola refused to grant non-discriminatory licenses for its sizeable portfolio of essential patents that turned out to be essential for GSM. Motorola was only prepared to enter into a limited number of cross-licenses with selected parties and also limited the geographic scope of such licenses to Europe.").

56. Bekkers \& Liotard, supra note 2, at 124

57. See 3GPP, About 3GPP, at http://www.3gpp.org/About/about.htm (last updated Feb. 17, 2003).

58. Id. (listing these and the other four organizational partners: ARIB and TTC of Japan, CWTS of China, and TTA of Korea). 
region." 59 GPP is not a legal entity but a "Partnership Project" devoted to settling on specifications for standards for $3 \mathrm{G}$ communication. ${ }^{60}$ The Organizational Partners implement 3GPP's general specifications by promulgating speeific standards that conform to 3GPP's specifications. ${ }^{61}$

$3 \mathrm{GPP}$ also delegates the task of forming intellectual property policy to the individual Organizational Partners. ${ }^{62}$ However, the partnership does require a number of intellectual-property-related tasks of its standardsetting members. Organizational Partners must

make their IPR [intellectual property right] Policy available for consideration by other Organizational Partners;

encourage that their IPR Policies are respected by their members (i.e. encourage their members to declare at the earliest opportunity any Intellectual Property Rights which they may have and believe to be essential, or potentially essential, to any ongoing work within 3GPP);

[and] encourage their respective members to declare their willingness to grant licenses on fair, reasonable terms and conditions on a non discriminatory [sic] basis, and consistent with their IPR Policy . . . ${ }^{63}$

Licensing arrangements are, at this time, wholly voluntary on the part of standard-setting bodies and essentially unregulated by 3 GPP itself. ${ }^{64}$

Apparently dissatisfied with either the limited geographical scope or the simple ineffectiveness of the Organizational Partners' licensingregulation efforts, however, a number of telecommunications companies have formed their own patent-pooling consortium. Known as the $3 \mathrm{G}$ Patent Platform (Platform), this organization exists symbiotically with 3GPP, not defining any standards but dealing with the intellectual property transactions needed to implement the 3GPP-based standards put forth by ETSI, the International Telecommunieations Union, and possibly other organizations. ${ }^{65}$ Pursuant to the Platform, a group of intellectual property attorneys

59. Third Generation Partnership Project Agreement, Dec. 4, 1998, at 1, available at http://www.3gpp.org/About/3gppagre.pdf [hereinafter 3GPP Agreement]. 3GPP also includes "Market Representation Partners," or organizations without standard-setting power that can offer advice about what the telecommunications market requires of its standards. Markct Representation Partners must be invited to participate by the Organizational Partners. Id. at 2 .

60. Id.; see also 3GPP, Frequently Asked Questions, at http://www.3gpp.org/faq/faq.htm\#A4.7 (last updated Feb. 17, 2003).

61. 3GPP Agreement, supra note 59, at 2 .

62. Id.

63. Id. at 3 .

64. 3GPP, Frequently Asked Questions, supra note 60. For policies of certain members, see supra Part 1.B.

65. See 3GPP, Frequently Asked Questions, supra note 60; see also UMTS Intellectual Propcrty Association, $3 G$ Patent Platform for Third Generation Mobile Communication Systems: Definition, Function, Structure, Operation, Governance, June 15, 2000 (on file with author) [hereinaftcr 3G Patent Platform Definition Draft]. 
has assembled to evaluate and certify "essential patents" for the $3 \mathrm{G}$ standards and will assist with the licensing of these patents. ${ }^{66}$ The Platform's status as a separate entity from the standard-setting bodies may enable it to focus more closely on IPR issues than the Organizational Partners have, and to institute a more comprehensive worldwide solution. However, this separation will probably also compromise the Platform's effectiveness. Companies can join the standard-setting bodies, influence them to adopt standards that include patented inventions, and then avoid the Platform's licensing obligations by simply declining to join the Platform.

The Platform views itself as the only solution to an extremely complicated tangle of intellectual property rights involved in the $3 \mathrm{G}$ standard. It estimates that more than one hundred entities own "technologies, which are called 'essential patents', necessary for the realisation of $3 \mathrm{G}$ systems." 67 The Platform claims to bring "defined meaning to the phrase, "fair, reasonable, and non-discriminatory, licensing of essential patents." " vocatively, the Platform, at least in its earlier drafts, aspired to cap the Maximum Cumulative Royalty Rate to $5 \%$ of the ex-works sales value of a product. ${ }^{69}$ However, it has since abandoned the $5 \%$ figure in favor of a number yet to be determined. ${ }^{70}$ Limiting the cumulative royalty rate to $5 \%$ or even $10 \%$ would be quite an accomplishment, given that up to $29 \%$ of the cost of a $2 \mathrm{G}$ mobile telephone stems from royalty payments. ${ }^{71}$

The basic function of the Platform is simply to replace the ordinary drawn-out, negotiated licensing process with a clearinghouse model. It is essentially a patent pool, a common arrangement in which patent owners agree to grant each other licenses, ${ }^{72}$ but one that is unusually ambitious in

66. Id.; Press Release, 3G, Launch of 3G Patent Platform Service (Jan. 10, 2003), at http://www.3g.co.uk/PR/Jan2003/4689.htm.

67. UMTS Intellectual Property Assoeiation and 3G Patent Platform Partnership, 3G Patent Platform for Third Generation Mobile Communication Systems: Definition, Function, Structure, Operation, Governance, Approved Public Version (Nov. 22, 2002), at 3, available at http://www.3gpatents.com/3g3p/9977qwebsite.pdf [hereinafter 3G Patent Platform Definition Final].

68. Id.

69. 3G Patent Platform Definition Draft, supra note 65, at 3. "[T]he ex-works sales value is the amount of the first sale of a licensed product to a party which is not a Related Company in which the ownership of the licensed product is transferred from the Licensee (or its Related Companies)." Id. at 10. This is the price paid by the first buyer that is not a subsidiary of a party to the agreement. See id. Given that mobile phones are typically sold by service providers or other retailers, rather than by manufacturers, the "ex works" price will probably be that charged by the device manufacturer to the service provider/retailer.

70. See id. $\S 8.2 .2$, at 27 ("The initial value of the MCR shall be [ ]\% per Produet Category .....").

71. Taaffe, supra note 54.

72. United States Dep't of Justice \& the Fed. Trade Comm'n, Antitrust Guidelines for the Licensing of Intellectual Property $\$ 5.5$ (1995), available at http:/www.usdoj.gov/atr/public/ guidelines/ipguide.htm ("Cross-licensing and pooling arrangements are agreements of two or more owners of different items of intellectual property to license one another or third parties."). Regarding patent pools, see generally Robert P. Merges, Contracting into Liability Rules: Intellectual Property Rights and Collective Rights Organizations, 84 CALIF. L. REv. 1293 (1996). 
its scope. ${ }^{73}$ The Platform provides a neutral arbiter that assesses patents that the owners believe are essential to the standard and determines whether they are indeed essential. ${ }^{74}$ The Platform then determines "default license" fees for the patents. ${ }^{75}$ The Platform's Web site praises the certainty that this deterministic approach will provide. ${ }^{76}$

The Platform and many of its participants, however, have indicated that they are seeking more than just efficiency and certainty from the arrangement. Specifically, a substantial component of the agenda of the Platform is the reduction of license fees associated with the production of wireless devices. ${ }^{77}$ As noted above, the Platform aims to limit the cumulative royalties associated with producing a standards-compliant device. ${ }^{78}$ The Platform Agreement incorporates this goal through the Maximum Cumulative Royalty concept. Royalties on members' essential patents are to be prorated such that, in total, they are limited to a certain percentage (for example, 5\%) of the ex-works sales value of a Product Category. ${ }^{79}$ Aware that such an arrangement would require the exchange of a substantial volume of pricing information, the Platform's Web site openly acknowledges the danger that the organization, once established, might facilitate price fixing within the mobile communications device industry. ${ }^{80}$

Some industry members have demonstrated reluctance to join the Patent Platform. The president of the organization that originally proposed the Patent Platform expects only $65-75 \%$ of the owners of essential $3 \mathrm{G}$

73. 3G Patent Platform Definition Final, supra note 67, at 3 ("Although Pools work well for certain technologies and products, the kinds of technologies and products involved with $3 \mathrm{G}$ require a more flexible approach. That approach, the 3G Patent Platform, is required for more complex standards and technologies.").

74. Id. $\S 6.2 .4$, at $16-17$.

75. 3G Patents Ltd., 3G Patent Platform: What, at http://www.3gpatents.com/3gplatform.htm (last updated Feb. 13, 2003).

76. 3G Patent Platform Definition Final, supra note 67, § 6.2.1, at 16 .

77. See id. $\S 6.2 .3$, at 15 (stating the Platform's desire to provide an "acceptable level of total cost of licenses").

78. Id. Note, however, that the current version of the Platform has softened the royalty-limiting language found in an earlier draft: the 2000 version stated that one objective of the agreement was to provide "an agreed structure of royalties ... the total cumulative cost of which is considered affordable within the industry ..." 3G Patent Platform Definition Draft, supra note 65, § 6.2.3, at 15 .

79. Id. $\S \S 8.2 .2-8.2 .4$, at 27-28; see also 3G Patent Platform Definition Final, supra note 67, annex E, at 90 (listing the five Product Categories as Base Station Type Equipment, Radio Network Controller Type Equipment, Terminals, Test Equipment, and "All products and/or services not covered by the other defincd Product Categories" and using 5\% as an example of the maximum cumulative royalty). The Platform's Maximum Cumulative Royalty policy will be discussed in more detail in Part III.

80. The 3G Patent Platform Company, Background History of the 3G Patent Platform, at http://www.3gpatents.eom/history/history.htm\#top (last updated Feb. 14, 2003). For background on this theory, see American Column \& Lumber Co. v. United States, 257 U.S. 377 (1921) (prohibiting an industry consortium that exchanged pricing information because it facilitated price fixing). But see Lemley, supra note 9 , at 1080-81 (noting similar fears regarding the Internet industry, but arguing that information exchange is worth suffering for the sake of interoperability and that some industries absolutely require standards based on shared information). 
patents to join the partnership. ${ }^{81}$ Wireless communications giant Qualcomm has been a noted dissenter ${ }^{82}$ perhaps because it focuses on licensing and not on manufacturing, and therefore stands to lose the most from a royalty-limiting system. ${ }^{83}$ Indeed, the Platform Agreement casts a bit of doubt on the rationality of any patent owner who chooses to join the Platform: "it is impossible to guarantee participation of ... patent holders whose sole interest is to maximise their licensing revenue." ${ }^{94}$ Especially for a nonmanufacturing patent holder who only wishes to license out its technology and not to obtain reciprocal licenses from others, there would seem to be no good reason to join the Platform. The lack of full industry-wide participation may dilute the competitive benefits of the Platform more than it dilutes its dangers. ${ }^{85}$

While the licensing rate limitation and lack of full industry-wide participation are the most immediately noticeable aspects of the Platform, certain other features of the Platform have, or should have, also figured into the antitrust authorities' decisions. One such feature is the "openness" of the agreement. Openness, as used herein, refers to whether parties who are not original members of a patent pool may nevertheless enter into it later, and to the ability of nonmembers to take advantage of the pool's licensing benefits without actually contributing their own intellectual property. ${ }^{86}$ Section 4.2 of the Platform Agreement indicates its degree of openness: "[T]he 3G Patent Platform shall be a 'single door' entry for evaluating, certifying and licensing Essential Patents for 3G Systems technology under a non-profit making control process which shall be open to all companies consenting to the mechanisms and arrangements of the $3 \mathrm{G}$ Patent Platform." ${ }^{87}$ This means that any party that wishes to obtain licenses from the Platform may do so according to the standard terms, as long as the new party becomes a member of the Platform, thereby "agree[ing] to

81. Peter Clarke, Royalty Cap of 5 Percent Proposed for $3 G$ Patents, eETimes, July 7, 1999, at http://www.eetimes.com/story/OEG19990702S0004. The article does not indicate what proportion of the essential $3 \mathrm{G}$ patents is actually owned by this $65-75 \%$ of the patent owners.

82. Anthony Cataldo, Possible "Showstoppers" Shadow $3 G$ Patent Pool, eeTimes, May 21, 1999, available at http://www.eet.com/story/OEG19990521S0014.

83. See Russ Arensman, Meet the New Qualcomm, Electronic Business, Mar. 1, 2000, available at 2000 WL 12306258 (quoting Qualcomm cofounder as saying, "[W]e'll do the innovative part and let others do the manufacturing"). In 2001, Qualcomm backed off somewhat from a strictly licensing-focused business model. Jennifer Davies, Qualcomm, in Shake-Up. Sets New Course; Vaunted Chip Spinoff Halted; President Resigns, SAn Diego Union-Tribune, July 25, 2001, at Al, available at 2001 WL 6474558. However, beeause the company has amassed a stable of bilateral $3 \mathrm{G}$ cross-licensing arrangements, the eompany may still feel that it does not need the Platform, even if it does wish to pursue 3G manufacturing. Qualcomm Halts Spin-Off in Corporate Restructure, ELECTRONICS WEEKLY, Aug. 1, 2001, at 6, available at 2001 WL 24338078.

84. 3G Patent Platform Definition Draft, supra note 65, §6.2.1, at 15.

85. See infra note 188 and accompanying text.

86. For more detail, see infra Part 11l.B.1.a.

87. 3G Patent Platform Definition Draft, supra note $65, \S 4.2$, at 12. 
certain standard non negotiable conditions for licensing terms and royalty rates ... in accordance with the basic principles [of the Platform]." other words, any entity may take advantage of the Platform's royalty rates so long as that entity promises not to withhold any of its own essential patents from the pool.

The contractual mechanism by which this provision operates is as follows:

There are three form contracts associated with the Platform: the Framework Agreement, the Standard License, and the Interim License. ${ }^{89}$

The Framework Agreement gives each member the choice either to license its essential patents according to the Standard License or to negotiate terms directly with a licensee. ${ }^{90}$

The Standard License prescribes standardized royalties for licenses, to be determined by an independent commission. ${ }^{91}$

If the patent owner foregoes the Standard License and fails to come to terms in bilateral negotiations, the Interim License comes into effect. ${ }^{92}$ The Interim License has the same royalty terms as the Standard License. ${ }^{93}$

In both the Standard and Interim Licenses, a "Licensee" is defined as "any individual, company, or other entity desiring a license to 3G Essential Patent(s) held by Licensor, for the use, sale, importation or final manufacture of a $3 \mathrm{G}$ Standard compliant product ....."94

Thus, for any Platform member, the default license fee for an essential patent is the fee set by the Platform. The licensee is free to negotiate bilaterally for a better rate, but will never be saddled with a worse one.

In summary, the $3 \mathrm{G}$ standardization process is operating essentially independently of the development of policies for licensing the patents needed to practice 3G standards. The 3G Patent Platform has emerged as the preeminent system for ensuring licenses will be available to those who wish to enter the $3 \mathrm{G}$ market. As an agreement among many competing businesses, the Platform naturally invites antitrust scrutiny. That scrutiny is discussed in Part III of this Comment.

88. 3G Patent Platform Definition Final, supra note $67, \S 6.1$, at 15 .

89. 3G Patent Platform Definition Draft, supra note 65, annex A-C, at 43-86.

90. Id. annex $\mathrm{A}$, art. 2.2 , at $44-45$.

91. Id. annex B, art. 3.1.1, at 62 .

92. Id. annex A, art. 2.5, at 45 .

93. Compare id. annex C, art. 3.1.1, at 76, with id. annex B, art. 3.1.1, at 62 .

94. Id. annex $\mathrm{B}$, art. 1.3, at 58; id. annex $\mathrm{C}$, art. 1.3, at 72 . 
II

\section{The European Commission's Competition LaW}

The European Commission (Commission) advises participants in the European market about the legality of their actions under European competition law. ${ }^{95}$ As an advisory body, its decisions technically lack force as legal precedent. ${ }^{96}$ However, those decisions contain the Commission's distillation of European antitrust law regarding the issue presented, providing "a measure of legal certainty[,]" and they are rarely, if ever, overturned by the courts. ${ }^{97}$ The law the Commission applies finds its genesis in Articles 81 and 82 of the European Community Treaty ${ }^{98}$ and in Article 2 of the Merger Control Regulation, ${ }^{99}$ and has been developed through the decisions of the European Court of Justice, Court of First Instance, and decisions of the Commission itself. ${ }^{100}$

The Commission, an administrative body, is the first "rung of the ladder" for Europe-wide antitrust challenges. Either the Commission or a private party may initiate a challenge. ${ }^{101}$ The Court of First Instance, and ultimately the European Court of Justice, can review the Commission's decisions. ${ }^{102}$ National courts can also hear cases and apply the same panEuropean competition law as the Commission does. Both the Court of First Instance and the European Court of Justice retain supremacy over national courts in their application of European law. ${ }^{103}$ Further, European Commission law preempts national law, at least when the former is more restrictive. ${ }^{104}$ Given the overwhelming prominence of pan-European competition law, only Commission law, and not the laws of the individual European countries, will be analyzed here.

This Comment first presents the foundation of European Community competition law, Article 81 of the European Community Treaty (also

95. See Treaty Establishing the European Economic Community, Mar. 25, 1957, art. 155, 298 U.N.T.S. 11 (Treaty of Rome), available at http://www.tufts.edu/departments/fletcher/multi/texts/ rome/contents.html.

96. LAROUCHE, supra note 4, at 115.

97. Id.

98. Consolidated Version of the Treaty Establishing the European Community, Dec. 24, 2002, art. 81, O.J. (C 325) 33, 64 (2002) (formerly art. 85 of the Treaty of Rome), available at http://europa.eu.int/comm/competition/legislation/treaties/ec/art81_en.html (last visited Aug. 25, 2003) [hereinafter EC TREATY]; id. art. 82 (formerly art. 86 of the Treaty of Rome), available at http://europa.eu.int/comm/competition/legislation/treaties/ec/art82_en.html (last visited Aug. 25, 2003).

99. Regulation (EEC) No. 4064/89 of 21 Dec. 1989 on the Control of Concentrations Between Undertakings, as amended by Regulation (EC) No. 1310/97 of 30 June 1997, 1997 O.J. (L 180) 1.

100. LAROUCHE, supra note 4, at 112-13. While the Commission's decisions are not binding on the courts, they do comprise a sort of academic development of European antitrust doctrine on which the Commission draws. See id. The Commission does possess some enforcement power, such as the power to levy fines. 2 HovenKamp ET AL., IP AND ANTITRust, $\S 45.3 \mathrm{~b}$ (Supp. 2003).

101. 2 HOVENKAMP ET AL., supra note $100, \S 45.3 \mathrm{c}$.

102. Id.

103. Id.

104. Id. 
known as the Treaty of Rome). Next, this Comment introduces the related concept of Block Exemptions, which protect certain categories of agreements between businesses. A discussion of the European courts' and the Commission's decisions in past intellectual property licensing cases follows.

\section{A. Article 81: The Foundation of European Antitrust Doctrine}

Europe's fundamental competition law appears on its face to declare the Platform illegal. But the situation is more complex than that-the Commission had to consider whether to exempt the Platform from the law's ban on agreements that distort competition.

Article 81(1) of the European Community Treaty states:

The following shall be prohibited as incompatible with the common market: all agreements between undertakings, ${ }^{105}$ decisions by associations of undertakings and concerted practices which may affect trade between Member States and which have as their object or effect the prevention, restriction or distortion of competition within the common market, and in particular those which:

(a) directly or indirectly fix purchase or selling prices or any other trading conditions;

(b) limit or control production, markets, technical development, or investment;

(c) share markets or sources of supply;

(d) apply dissimilar conditions to equivalent transactions with other trading parties, thereby placing them at a competitive disadvantage;

(e) make the conclusion of contracts subject to acceptance by the other parties of supplementary obligations which, by their nature or according to commercial usage, have no connection with the subject of such contracts. ${ }^{106}$

Article 81 bears superficial resemblance to Section 1 of the Sherman Act in the United States. ${ }^{107}$ Article 81 prohibits anticompetitive arrangements between businesses. It further contains a list of explicitly prohibited categories of behavior that approximate those prohibited "per se" in U.S. antitrust law. However, instead of dividing the world of intercorporate agreements into "per se" and "rule of reason" sectors, Article 81 condemns all competition-distorting arrangements, but carves out a series of

105. An "undertaking" is "any entity engaged in an economic activity, that is an activity consisting in offering goods or services on a given market, regardless of its legal status and the way in which it is financed..." European Commission, Glossary (2003), at http://europa.eu.int/comm/competition/ general_info/u_en.html\#t62.

106. EC TREATY, supra note 98.

107. 2 HOVENKAMP ET AL., supra note $100, \S 45.3 \mathrm{~b}$. 
exemptions for specific types of arrangements. ${ }^{108}$ The exemptions find expression in Article 81(3), which allows the Commission to declare Article 81(1) inapplicable to:

- any agreement or category of agreements between undertakings;

- any decision or category of decisions by associations of undertakings;

- any concerted practice or category of concerted practices, which contributes to improving the production or distribution of goods or to promoting technical or economic progress, while allowing consumers a fair share of the resulting benefit, and which does not:

(a) impose on the undertakings concerned restrictions which are not indispensable to the attainment of these objectives;

(b) afford such undertakings the possibility of eliminating competition in respect of a substantial part of the products in question. ${ }^{109}$

When applied to particular parties or agreements, the exemptions are called "individual exemptions," while "block exemptions" exempt whole categories of business practices. The block exemptions contain the real substance of the European Community's competition law doctrine regarding agreements between businesses. ${ }^{110}$ Few of the Commission's conclusions have been challenged in court, although litigation has helped to clarify which practices do and do not fall within the ambit of the exemptions.

\section{B. New Block Exemptions, Individual Exemptions, and "Comfort Letters"}

The European Commission has used a number of methods to fill out the exemptions list. The Commission initially generated new exceptions either by rendering decisions in individual cases (creating individual exemptions) or by promulgating new regulations (establishing block exemptions). Eventually, rather than pursue a case to its end, the Commission developed a "comfort letter" process whereby it would issue letters stating its intent not to challenge an arrangement. ${ }^{11}$ Procedural reforms adopted in 2002 are expected to curtail the use of comfort letters, so regulations are

108. Id. Under U.S. law, certain practices deemed anticompetitive, such as price-fixing cartels, are barred per se, without regard to purported justifications in individual cases. United States v. SoconyVacuum Oil Co., 310 U.S. 150 (1940). For certain other types of practices, a "rule of reason" is applied; courts weigh the procompetitive and anticompetitive aspects of a particular arrangement rather than approving or rejecting it according to a per se rule. See generally Standard Oil Co. v. United States, 221 U.S. I (1911) (holding that the Sherman Act's prohibition on all restraints of trade should, at least in some categories of business practices, be interpreted to bar only those particular restraints that unreasonably limit competition).

109. EC TREATY, supra note 98.

110. Id. $\S 45.4 \mathrm{a} 4$.

111. Id. 
generating renewed interest. ${ }^{112}$ One of the Commission's regulations, the Technology Transfer Block Exemption, deals specifically with the licensing of patents. ${ }^{13}$

\section{The Technology Transfer Block Exemption}

The block exemption for technology transfer, which was given its current form by a 1996 Commission regulation, governs intellectual property licensing in Europe. ${ }^{114}$ Finding that certain types of restrictions on licenses, such as exclusivity, "generally contribute to improving the production of goods and to promoting technical progress," the Commission compiled lists of prohibited license restrictions ("black list"), allowable restrictions ("white list"), and restrictions upon which it reserved judgment ("grey list"). ${ }^{115}$ Among the grey-listed provisions are those prohibiting licensees from contesting the validity of a patent. ${ }^{116}$ However, the Commission has allowed such provisions if the only consequence of such a contest is that the licensor may terminate the license. ${ }^{117}$ The block exemption also addresses grant-back clauses and tying. Grant-back clauses, in which a licensee agrees to grant the licensor certain rights in any patents the liccnsce receives on improvements to the licensed invention, may only require cross-licensing between the contracting parties; those that require the licensee to actually assign the improvement patent to the licensor are blacklisted. ${ }^{118}$ Tying, the practice of requiring the purchase of a certain product as a condition for licensing a patent, is white-listed if it is necessary for "a technically proper exploitation of the licensed technology. . .."119

112. Id. Mario Monti, European Competition Policy: Quo Vadis?, Address Before the XX International Forum on European Competition Policy (Apr. 10, 2003), available at http://europa.eu.int/ comm/competition/speeches/index_speeches_by_the_commissioner.html.

113. 2 HovenKAMP ET AL., supra note $100, \S 45.4 \mathrm{a} 4$.

114. Jianming Shen, Block Exemption for Technology Licensing Agreements Under Commission Regulation (EC) No. 240/96, 20 B.C. INT'L \& CoMP. L. REv. 251 (1997). The Commission is eurrently working on revising the Technology Transfer Block Exemption. See Europcan Commission, Summary of Submissions on TTBE Review Report at 1, at http://europa.eu.int/comm/competition/antitrust/ teehnology_transfer/summary_of_comments.pdf (July 19, 2002).

115. Id. at 254 (quoting Commission Regulation (EC) No $240 / 96$ of 31 Jan. 1996 on the Application of Article 85(3) of the Treaty [of Rome] to Certain Catcgories of Teehnology Transfer Agreements, 1996 O.J. (L 31) 2 [hereinafter Reg. 240/96]); Sara M. Biggers et al., Intellectual Property and Antitrust: A Comparison of Evolution in the European Union and United States, 22 Hastings 1NT'L \& COMP. L. REv. 209, $237-41$ (1999) (charaeterizing the black, white, and grey lists).

116. 2 HovenKAMP ET AL., supra note $100, \S 45.4 \mathrm{bl}(\mathrm{C})$.

117. Id.

118. Id.

119. Id. (quoting Reg. 240/96, supra note 115 , art. $2, \S 1(5)($ a)). A classic example of tying occurred in International Business Machines Corp. v. United States, 298 U.S. 131 (1936) (holding that $1 \mathrm{BM}$ violated antitrust law by leasing patented machines for reading cards with holes punched in them under the condition that lessees only buy the cards from 1BM). 
Regarding patent pooling, the Technology Transfer Block Exemption takes a hands-off approach. ${ }^{120}$ Article 1 of the exemption disclaims any effect on multilateral patent pools, stating that the regulation applies to licenses "to which only two undertakings are party." 21 The law governing multilateral patent pools will apparently be assembled case by case. Still, one would imagine that the Commission intends to apply similar rules to bilateral or multilateral patent pools. Therefore, the Technology Transfer Block Exemption probably played a persuasive role in the assessment of the Patent Platform, despite the exemption's deliberate reservation of group-licensing issues.

\section{Exceptions Developed in Individual Cases}

Outside the realm of specific block exemptions, the Commission has recently treated licensing arrangements more leniently than it has in the past. Whereas, once, the Commission had treated essentially all licenses in which both the licensor and the licensee ultimately produced the same product as horizontal agreements, it now tends to look at whether the two were competitors at the time the license was being negotiated. ${ }^{122}$ If they were not, then the Commission considers the agreement vertical and will probably not condemn it. ${ }^{123}$

Still, ample precedent exists to support a hard-line approach to the approval of patent-pooling arrangements. For example, in a dispute in the early 1980s involving Comcast and Mannesmann, the Commission pursued an investigation of the firms until they terminated their agreement. ${ }^{124}$ The firms merely agreed to cross-license their patents for continuous metallic

120. Indeed, the Commission has developed a habit of scrupulously avoiding the regulation of patent pools through block exemptions. See Reg. 240/96, supra note 115, pmbl. \& 8 ("Also to be excluded from the scope of this Regulation are ... certain licensing agreements entered into in connection with arrangements such as joint ventures or patent pools.... Such agreements pose different problems which cannot at present be dealt with in a single regulation..."); Commission Regulation (EEC) No 556/89 of 30 Nov. 1988 on the Application of Article 85(3) of the Treaty to Certain Categories of Know-how Licensing Agreements, 1989 O.J. (L 61) 1, pmbl. § 5 ("Also excluded from the scope of the Regulation are agreements relating ... to know-how agreements entered into in connection with arrangements such as joint ventures or patent pools ...."); Commission Regulation (EEC) No 2349/84 of 23 July 1984 on the Application of Article 85(3) of the Treaty to Certain Categories of Patent Licensing Agreements, 1984 O.J. (L 219) 16, pmbl. § 8 ("Since the experience so far acquired is inadequate, it is not appropriate to include within the scope of the regulation patent pools ....").

121. Reg. $240 / 96$, supra note 115 , art. 1 .

122. Valentine Korah, Technology Transfer Agreements and the eC Competition RuLES 23 (1996).

123. Id. at 23-24. A "horizontal" agreement is one in which the parties operate at the same level of commerce, such as when they are both retailers. A "vertical" agreement is made by two parties that operate at different levels, such as a retailer and a wholesaler. Horizontal agreements are generally considered more damaging to competition. See, e.g., Continental T.V., Inc. v. GTE Sylvania Inc., 433 U.S. 36, 54-55 (1977) (discussing the "redeeming virtues" of vertical agreements between businesses).

124. KORAH, supra note 122, at 97 (citing Commission of the European Communities, Eleventh Report on Competition Policy, § 4, point 93 (1982) [hereinafter Eleventh Report]). 
castings on a royalty-free basis. ${ }^{125}$ The Commission challenged the agreement because it eliminated potential competition in innovation between the two companies, and because it encouraged customers to deal with these firms, which already had large market shares that made them a near duopoly. ${ }^{126}$

The Commission has also shown some hostility toward patent pools that exclude outsiders who want to enter the pools ex ante. In IGR Stereo Television, ${ }^{127}$ a pair of German television-industry innovators assigned their patents to IGR, an industry organization consisting of all the German stereo television manufacturers. ${ }^{128}$ The IGR patents were necessary for producing stereo televisions according to the German transmission standard; without the patents, one could not make a television set that would receive stereo signals in Germany. ${ }^{129}$ IGR licensed the patents to all its members, but placed temporal and quantity restrictions on licenses to nonmembers. ${ }^{130}$ When IGR prevented a Finnish manufacturer from selling in Germany, the Finnish company complained to the Commission. The Commission then declared that the arrangement constituted an anticompetitive horizontal agreement and therefore violated Article $85(1) \cdot{ }^{131}$ The Commission's subsequent threat to impose compulsory licensing measures induced IGR to open its licensing scheme fully to outsiders. ${ }^{132}$

On the other hand, five years later the Commission gave favorable treatment to a software industry standard-setting association in X/Open Group. ${ }^{133}$ This case involved an organization devoted to setting standards for compatibility with AT\&T's Unix. ${ }^{134}$ The criteria and procedures for admission to membership effectively excluded certain companies, putting them at a competitive disadvantage before publication of the standards. ${ }^{135}$ The Commission, however, trusted the members' assurances that the

125. KORAH, supra note 122, at 97.

126. Id.

127. Eleventh Report, supra note $124, \S 4$, point 94.

128. KORAH, supra note 122, at 102 (citing Eleventh Report, supra note 124, and Commission of the European Communities, Fourteenth Report on Competition Policy, $\S 5$, point 92 (1985) [hereinafter Fourleenth Report]).

129. Lang, supra note 52, at 16 (citing Eleventh Report, supra note $124, \S 3$, point 63 , and Fourteenth Report, supra note $128, \S 3$, point 76 ).

130. KoraH, supra note 122, at 102 (citing Eleventh Report, supra note $124, \S 3$, point 63 , and Fourteenth Report, supra note $128, \S 3$, point 76 ).

131. Id.

132. $I d$

133. 1987 O.J. (L 35) 36; see also Lang, supra note 52, at 17.

134. Lang, supra note 52 , at 17.

135. Id. The standard was to be public, not proprietary, so there were no IPRs that would prevent nonmembers from using the standard. But membership conveyed "first-mover" advantages because members would know the details of the standard before nonmembers would. Id. 
organization would mitigate this anticompetitive effect by publishing standards as quickly as possible; it therefore granted a four-year exemption. ${ }^{136}$

However, the Commission again asserted its antitrust authority against an intellectual-property-related agreement in MSG Media Service. ${ }^{137}$ MSG involved a proposed joint venture by a state-run telecommunications company (Deutsche Telekom), a maker of movies and television programs (Kirch), and a book and music publisher (Bertelsmann). ${ }^{138}$ The joint venture was formed to provide cable and satellite television in Germany. ${ }^{139}$ The Commission seemed to accept that the market for cable and satellite television decoders, which were necessary for most German televisions to receive the signals, would converge on Deutsche Telekom's standard. ${ }^{140}$ However, the Commission strove to prevent the owner of that standard from participating in downstream markets, such as television show and film production, in which control of the standard for decoders might give it an unfair advantage. ${ }^{141}$ The Commission therefore prohibited the joint venture. ${ }^{142}$

Thus, while the Commission has seemed to avoid broad pronouncements about patent pools, in individual cases it has tended to regulate them rather tightly. This tendency has shown itself again in the Commission's imposition of a number of conditions on the Platform in the course of allowing it to go forward.

\section{III}

\section{ANALYSIS}

\section{A. The Japanese Fair Trade Commission's Early Clearance of the Platform}

While this Comment is primarily devoted to the European Union's approach to the $3 \mathrm{G}$ patent licensing arrangements, it is instructive to examine what the Japanese antitrust authorities did with the Platform. The Japanese Fair Trade Commission (JFTC) was the first of the world's three major antitrust authorities to approve the Platform wholesale. Japan thus became the first nation with a large multilateral licensing scheme to pave the way for commercial implementation of $3 \mathrm{G}$ technology.

136. The Commission also imposed a requirement to notify it every time the organization rejected an application for membership in the standard-setting body.

137. 1994 O.J. (L 364) 1; see also Lang, supra note 52, at 20-22.

138. Lang, supra note 52 , at 21 .

139. Id. at 20.

140. See id. at 21 .

141. Id.

142. Id. 
The JFTC pronounced the Platform legal under the country's Antimonopoly Act. ${ }^{143}$ The JFTC determined the savings in transaction costs associated with a license clearinghouse would facilitate utilization of patents and improve the prospects for entry by telecommunications equipment manufacturers into the market. ${ }^{144}$ It therefore called the arrangement procompetitive. ${ }^{145}$

The JFTC praised the Platform's openness. Because the Platform is intended to include all $3 \mathrm{G}$ standards, the Commission reasoned, it will facilitate competition among those standards by allowing licensees to select from among them and to design for compatibility with multiple standards. ${ }^{146}$ The Platform's willingness to accept new members also supported the JFTC's conclusion that it was not exclusionary. ${ }^{147}$ A licensee's complete freedom to determine which patents it needs-contrasted with the "bundling" arrangements that have characterized some other patent pools-further bolstered the case in the Platform's favor. ${ }^{148}$

The JFTC reviewed the Platform's effect on competition not only in the mobile communications product market, but also in the innovation market (that is, the competition among businesses to create better technologies) and among standards (the mobile communications standards also compete with each other, like VHS and Betamax once did). ${ }^{149}$ While this breadth of analysis was impressive, the depth of the JFTC's reasoning left something to be desired. While acknowledging that sharing of pricing information was necessary to determine royalty rates under the Platform's Maximum Royalty Rate provision, and that exchange of price information can facilitate price fixing, the JFTC determined that individual companies' freedom to negotiate a lower bilateral royalty rate between themselves rendered the price fixing danger insignificant. ${ }^{150}$ It apparently did not consider the suggestion of certain U.S. antitrust commentators, who have argued that maximum price fixing may actually represent minimum price fixing in disguise. ${ }^{151}$ However, given the Platform's efforts toward a 5\% Maximum

143. Japanese Fair Trade Commission, supra note $14, \S 3$. Note that the reasoning analyzed herein is found in the JFTC's "Views" issued in December 2000 and not the offieial approval granted in June 2002 , because the 2000 opinion provides the rationale for the approval.

144. Id. §2.1.3.

145. Id.

146. Id. $\S 2.1 .1$.

147. Id. § 2.1.2.

148. Id.

149. Id. $\S 2.2$.

150. Id. $\S 2.2 .1$.

151. See, e.g., Phillup Areeda \& Louls Kaplow, Antitrust Analysis 228 (5th ed. 1997); Aaron S. Edlin, Do Guaranteed-Low-Price Policies Guarantee High Prices, and Can Antitrust Rise to the Challenge?, 111 HARv. L. REv. 528 (1997) (arguing that retail stores' lowest-price guarantees facilitate supracompetitive pricing by allowing the stores to discriminate between informed and uninformed consumers); see also Arizona v. Maricopa County Med. Soc., 457 U.S. 332 (1982) (holding a horizontal maximum price-fixing arrangement illegal per se); ef. State Oil Co. v. Kahn, 522 
Cumulative Royalty Rate, far below the typical ratc for $2 \mathrm{G}$ devices, the JFTC was probably correct about this issue.

In addressing the innovation question, though, the JFTC devoted a scant two sentences to what should have been a very important issue in the analysis. Because "only the essential patents are to be licensed under the Platform and any competing patents are not included," the JFTC declared that the Platform would do no harm to innovation within standards. ${ }^{152} \mathrm{Fi}$ nally, the JFTC reasoned that the ability of Platform licensees to choose among the various standards (assuming, of course, that the members of 3GPP produce more than one standard) indicated that the Platform did not restrict competition among standards. ${ }^{153}$

\section{B. The European Commission's Conditional Approval of the Platform}

The Commission has recently approved the Platform. The Platform met the threshold for consideration under Article 81(1) of the European Community Treaty because the Commission considers all licensing agreements as distorting competition to some extent. This overarching principle is not dispositive, however, because so many practices that distort competition are exempt from the reach of Article 81(1).

Nonetheless, it was clear that no block exemption supported the legality of the Platform. The Commission has repeatedly stated its intention to treat patent pools on a case-by-case basis and has specifically excluded them from Article 81(3) and from each of the subsequent regulations establishing block exemptions for various intellectual property licensing arrangements. Therefore, to gain Commission approval, the Platform had to merit an individual exemption. ${ }^{154}$

Having not yet weaned itself from settling individual exemption cases by issuing confidential "comfort letters" to the interested parties, the Commission failed to issue a public opinion explaining its approval of the Platform. ${ }^{155}$ Therefore, the remainder of this Section analyzes the approval in light of European Community law (with an emphasis on Commission preccdent) and press coverage of the decision.

In determining whether to grant an individual exemption, the Commission considers whether an agrcement has an anticompetitive object or effect and whether this effect is appreciable. The "object or effect" step

U.S. 3 (1997) (declaring that vertical maximum price fixing agreements should be analyzed under the rule of reason).

152. Japanese Fair Trade Commission, supra note 14, $\$ 2.2 .2$.

153. Id. $\S 2.2 .3$.

154. Bryan Harris, Technology Licensing in the European Union, 38 IDEA 139, 140 (1997) (indicating that only individual exemptions can save a technology transfer agreement not eovered by block exemptions and that the individual exemption procedure can be "slow and hazardous").

155. The reforms mentioned in Hovenkamp et al.'s treatise that would eliminate this procedure have apparently not yet gonc into effect. See 2 HoveNKAMP ET AL., supra notc 100, § 45.4a4. 
is the significant one in this particular inquiry because, in a project as massive and wide ranging as the Platform, even slight anticompetitiveness will substantially affect commerce in the European Community. Because the second prong of the test is so obviously satisfied, it does not require further analysis.

Numerous other policy considerations influenced the Commission's decision. The first Section of this analysis attempts to identify the features that led the Commission to approve the Platform. ${ }^{156}$ The next Section analyzes the Commission's conditions for continued acceptance of the Platform. Part IV follows with a discussion of standards capture, which apparently did not figure into the Commission's analysis, but may prove to be an intractable problem under the Platform.

\section{Features of the Platform That Likely Favored the Commission's Approval}

\section{a. Openness}

One factor that probably swayed the Commission toward acceptance of the Platform is the patent pool's openness to outsiders. In IGR Stereo Television, the case that appears most on point for the Platform analysis, the closed nature of the patent pool induced the Commission's challenge. ${ }^{157}$ $I G R$ demonstrates the Commission's goal of promoting openness in patent pools. ${ }^{158}$

The Platform's drafters seem to have done their homework on this point. The Framework Agreement for the Platform requires members to license essential patents, under the standard terms, to any entity that comes calling, unless that entity is withholding essential patents of its own. ${ }^{159}$ It would be difficult to explain this sacrifice of market power except as a deliberate effort to assuage antitrust regulators' concerns. Especially because $I G R$ figures so prominently in European antitrust and intellectual property doctrine, ${ }^{160}$ the conclusion that drafters included the openness provision as

156. Given that the Commission did not issue a formal opinion stating the reasons for its action, this Section is necessarily rather speculative. The analysis of the factors weighing against approval of the Platform is less spcculative because these ncgative factors can be gleaned from the conditions of that approval, which were listed in a press release issued by the Commission. European Commission, supra note 15.

157. See KORAH, supra note 122, at 102 (discussing IGR Stereo Television).

158. Lang, supra note 52, at 16-17.

IGR and its members would not have been permitted to shut [a competitor] out of the Germany market while exploiting it themselves. If necessary, the Commission would have ordered compulsory licensing by IGR; ... although in general there is no duty to supply under Article 85 , there is a duty when a discriminatory refusal has sufficiently serious anticompetitive effects.

Id.

159. See supra notes $72-80,86-94$, and accompanying text.

160. Many discussions of European antitrust and intellectual property law cite this case and give it extended treatment. See, e.g., KoRAH, supra note 122, at 102; Lang, supra note 52, at 16. 
a compliance measure specifically for European authorities does not seem particularly far-fetched. Regardless, the openness feature places the Platform squarely in compliance with the rule that seems to follow from $I G R$. The Commission, therefore, apparently viewed this feature positively.

\section{b. Transactional Efficiencies}

Several of the Platform's features will undoubtedly produce competitive efficiencies in the wireless communications equipment market. The "automatic" licensing procedure, governed by a neutral decision-making body, reduces transaction costs by eliminating negotiation over individual licenses ${ }^{161}$ and reducing the likelihood of infringement litigation. ${ }^{162}$ Further, as a cross-licensing arrangement, the Platform will remedy the "blocking patents" problem, thereby ensuring that innovations will actually reach consumers and do so more quickly than under a bilaterally negotiated licensing regime. ${ }^{163}$ The Commission apparently recognized the value of the Platform for increasing transactional efficiencies, because it described the Platform as having "procedures... to streamline the licensing of those [patents that are] deemed essential..."" 164 Reducing transaction costs eliminates wasteful spending on negotiations for every market participant, and, in particular, allows smaller competitors who are less able to bear that transactional cost to enter the market; therefore, the Commission was correct in highlighting transactional efficiencies as a reason to approve the Platform.

\section{c. Ease of Entry}

The Platform's Web site touts ease of entry as one of its leading benefits, ${ }^{165}$ but all this hype might arouse suspicion: why would companies already in a market wish to provide a mechanism that paves the way for new entrants? The most likely answer is that because the $3 \mathrm{G}$ market is still in an early stage of development, most $3 \mathrm{G}$ manufacturers are still potential entrants. Because no one could start manufacturing $3 \mathrm{G}$ devices today

161. More precisely, the Platform eliminates the need to negotiate individual licenses. The parties are free to forgo the Platform's default licensing structure and negotiate bilaterally if they wish. 3G Patcnt Platform Definition Final, supra note 67, § 6.5.7, at 20.

162. Id. $\S 5$, at 12 (licensing costs); id. annex A, pmbl., at 43 (litigation costs; "Patent Holder recognises that a determination by the Evaluation Board that its Patent(s) are essential to practice the 3G standard will reduce the ... need to monitor use of and enforce such Patent(s).").

163. See id. $\S \S 5,6.1$, at 12-15; The 3G Patent Platform Company, supra note 80. The term "blocking patents" applies to thc situation in which several different patcnted components are needed to make a particular product, and the patents are not all owned by a single cntity. Because patent law gives each patent owncr the right to prevent the others from making or using that owner's patented component, none of the entities can legally make the product without obtaining licenses from the other ones. The entities can solve the blocking patents problem by granting each other cross-licenses to their respective patents.

164. European Commission, supra note 15, at 2

165. The 3G Patent Platform Company, supra notc 80. 
according to any recognized standard without infringing someone else's patents, all manufacturers want to make' the process of obtaining licenses and entering the market easier. Another probable reason for the Platform's focus on entry is the influence of the many small innovators in the Third Generation Partnership Project who may contribute only one or two patents to the project and therefore would lack the leverage to enter the market through bilateral licensing. ${ }^{166}$

The main reason companies already in the market may provide ready access for newcomers, though, is probably conformance with the policy favoring openness discussed above. Because of the openness provision, the Platform does not create privileged classes of firms with a wider point of entry into the market. A closed patent pool would have provided cheap and convenient cross-licensing for those firms that contributed essential patents but would have handicapped firms without essential patents by denying them the standardized licenses. Thus, the openness provision also saves the Platform from contravening competition law's policy of facilitating entry; from the perspective of entry, the Platform is procompetitive. Apparently, this characteristic also encouraged the Commission to approve the Platform; it stated that "[i]mproved access to patents is essential for a rapid introduction of $3 \mathrm{G}$ mobile services in Europe."167

\section{d. Reduction of Prices for Consumers}

Although the end-user cost-reduction argument is somewhat speculative and was de-emphasized by the Platform in its later draft, the Commission still made note of it. ${ }^{168}$ The Platform claims that its cap on license fees, the Maximum Cumulative Royalty provision, will reduce the prices consumers will pay for mobile communications devices. Although consumers may indeed pay less, the cost reduction may be insubstantial if licensors of important technology stay out of the patent pool. ${ }^{169}$ Because

166. Yet another reason is the lack of influence of three major patent owners who have decided not to partieipate in the Platform. Following Qualcomm's lead, discussed above, Nokia and Ericsson have also opted out of the agreement. Nick Lane, Risk of Patent Poker Too High a Gamble for Nokia, 3G MoBILE, Jan. 22, 2003, at 1-2, available at http://www.3gpatents.com/news/3GM-20030122.pdf. Major holders of essential patents who opt out of the Platform would not care if the Platform facilitated the entry of competitors, because the nonparticipating patent holders can still use their own patents to restrict entry, if they so choose.

167. European Commission, supra note 15, at 1.

168. Compare 3G Patent Platform Definition Final, supra note 67, $\$ 6.2 .3$, at 16 ("The 3G Patent Platform shall provide an agrced structure of royalties: the total cost of which by virtue of efficient determination and licensing of essential patents is less than would bc the case if Essential Patent holders negotiated individual licenses with everyone...."), with 3G Patent Platform Definition Draft, supra note $65, \S 6.2 .3$, at 15 ("The $3 \mathrm{G}$ Patent Platform shall provide an agreed structure of royaltics: the total cumulative cost of which is considered affordable within the industry...."), and European Commission, supra note 15, at 1 (stating that the Platform possessed procedures dcsigned "to reduce the overall license fees to be paid for the entire portfolio of essential patents").

169. This appears to be happening. See supra text accompanying note 166 . 
these licensors could command relatively high royalty rates, the impact of capping rates for members of the patent pool might be slight. Still, any price cut, even a small one, provides at least a small competitive benefit. This factor probably weighed slightly in favor of Commission approval.

\section{e. Horizontal versus Vertical Agreements}

One factor that appears generally important to the Commission, but may not have played a substantial role in the approval of the Platform, is whether an agreement is between horizontally or vertically related entities. Vertical agreements, in recent years, have often received the Commission's endorsement. ${ }^{170}$ However, the Commission has not used consistent criteria to determine which agreements fall into which category, ${ }^{171}$ and the Platform is particularly likely to present such difficulties. At least in theory, the Platform includes every entity that owns patents essential to manufacturing wireless devices according to the $3 \mathrm{G}$ standards of the International Telecommunication Union (ITU) and the European Telecommunications Standards Institute (ETSI). ${ }^{172}$ Some of these entities are probably device assemblers, some integrated circuit manufacturers, some software producers, some wireless service providers, and some all of the above. Who sells to whom in this complex network is a question that is probably not worth answering because it would not lead to a clear conclusion that the Platform is either a horizontal or a vertical agreement. The Platform is a hybrid of horizontal and vertical agreements because its participants compete with each other in the product market but buy and sell among each other in the market for intellectual property. The antitrust consequences of this situation are not particularly clear, so other factors likely weighed more heavily in the assessment. ${ }^{173}$

\section{The European Commission's Conditions for Approval of the Platform}

The European Commission's approval of the Platform was neither irrevocable nor unconditional. In a brief press release announcing the approval of the Platform, the Commission indicated that it reserved the right to reevaluate the Platform in light of "any significant change in the factual or legal situation ...."174 It also expressed a number of concerns about the

170. For example, see Commission Regulation (EC) No. 2790/1999 of 22 Dec. 1999 on the Application of Article 81(3) of the Treaty to Categories of Vertical Agreements and Concerted Practices, 1999 O.J. (L 336) 21 (prescribing a block exemption applicable to many vertical agreements).

171. KORAH, supra note 122, at 23.

172. See 3G Patent Platform Definition Draft, supra note 65, annex A, art. 1.1, at 43 (defining a licensee as any party seeking to license essential patents for use in products compliant with 3G standards).

173. See European Commission, supra note 15 (failing to discuss whether the agreement is horizontal or vertical).

174. Id. at 1 . 
Platform's potential effect on competition, hinting that it would challenge the agreement if it saw any of these concerns becoming reality. ${ }^{175}$ Specifically, the Commission required each of the five $3 \mathrm{G}$ "radio interfaces" (a term for a broad category of technology that can encompass multiple standards) to have its own, separate Platform Company, ${ }^{176}$ and it stated that clearance under the antitrust rules requires that each licensing agreement is limited to essential patents only, that the agreements do not foreclose competition in related or downstream markets, licensing should be carried out under non-discriminatory terms and competitively sensitive information is not exchanged. Furthermore, 3G manufacturers should not be forced to pay for patent rights other than those that they really need. Finally, the licensing arrangements should not discourage further R\&D and innovation in the mobile communications sector. ${ }^{177}$

The more significant of the Commission's concerns will be analyzed in turn.

\section{a. The Requirement of Competition Among the Radio Interfaces}

To preserve competition among standards, the Commission (and the United States Department of Justice) ordered modifications to the Platform to establish separate and independent Platform Companies for each of the five ITU-approved $3 \mathrm{G}$ radio interfaces. ${ }^{178}$ According to the Commission, this change would "safeguard competition" among the different technologies, whether that competition was based on the price of licenses or the performance of the technology. ${ }^{179}$

The separation of the licensing organization into five competing units will probably diminish the cartel-like nature of the Platform, but only slightly. In effect, the provision slices a potential $3 \mathrm{G}$ intellectual property cartel into a number of smaller radio interface cartels, each of which is theoretically capable of dominating its particular radio interface. In reality, though, competing technologies were already at work- $3 \mathrm{G}$ will be competing with the various forms of $2.5 \mathrm{G}$, the forthcoming $4 \mathrm{G}$, and another technology called $\mathrm{Wi}-\mathrm{Fi}$, so it was probably unnecessary to require the Platform to subdivide into a larger number of competing technologies. ${ }^{180}$ Putting that issue aside, the Platform does not seem to be a very egregious

175. Id. at 2 .

176. Id.

177. Id.

178. Id.

179. Id.; see also Letter from Charles A. James, supra note 15, at 10 ("There is a reasonable possibility that the five $3 \mathrm{G}$ radio interface technologies will continue to be substitutes for each other, and we would expect the owners of intellectual property rights essential to these technologies to compete, including through price, to persuade operators to adopt their technology.").

180. See Press Release, 3G, 2.5G / 3G Over Wi-Fi and 4G (Mar. 5, 2003), at http://www.3g.co.uk/PR/March2003/4996.htm. 
example of a cartel in the first place. As noted above, the Platform is in some respects a vertical agreement, which is less harmful to competition than a purely horizontal one. And as discussed below, the Platform is unlikely to be very effective at limiting competition on either price or quality of $3 \mathrm{G}$ products. Ultimately, ensuring competition among the radio interfaces may have been a red herring that distracted the Commission from more significant problems with the Platform's structure. ${ }^{181}$

\section{b. Avoiding the Restriction of Competition in Downstream Markets}

In expressing its concern over the Platform's effect on related and downstream markets, the Commission revisited an issue that arose in past competition law decisions. This issue was the principal concern of the Commission in MSG Media Service. ${ }^{182}$ The Platform's case is distinguishable from $M S G$ on two grounds. First, unlike the German cable television decoder market, the $3 \mathrm{G}$ market is not particularly likely to converge on a single standard. Because one standard will not necessarily dominate, patents related to that standard will probably not create the kind of market power that they did in $M S G$. Second, the level of integration among the Platform's participants is considerably less than it was for the participants in $M S G$ 's joint venture. Given that the Platform only exists to facilitate licensing, upstream companies have no significant motivation to act for the benefit of particular downstream companies. Bearing these facts in mind, the Commission's decision to refer to the possibility of interference in downstream markets, without actually challenging the Platform on this basis, seems sound.

\section{c. Avoiding the Facilitation of Price Fixing}

Next, there is the widely acknowledged danger that the Platform may facilitate price fixing. ${ }^{183}$ Calculation of the MCR will almost certainly require members to divulge pricing information to each other, a notion that raised alarm in the Commission. However, price disclosure did not prevent the Commission from approving the Platform, probably because the Platform shows few signs of being able to maintain a system of price fixing among its dozens of likely members. ${ }^{184}$ In an appropriate response to the potential price-fixing problem, the Commission has reserved the right to challenge the Platform if its behavior, in practice, begins to show signs of price fixing. ${ }^{185}$

181. See infra Part IV

182. 1994 O.J. (L 364) 1; Lang, supra note 52, at 13.

183. See supra note 80 and accompanying text.

184. A price-fixing cartel requires policing of members' actions to prevent cheating; otherwise, thc cartel loses its effectiveness. Policing would be extremely difficult in a cartel with many members. AREEDA \& KAPLOW, supra note 151, at 166-68.

185. European Commission, supra note 15 , at 1. 


\section{d. Ensuring That the Platform Does Not Discourage Innovation}

Although the Platform's royalty cap will probably lower consumer prices, it might also hinder competition by deterring quality improvement. By fixing maximum prices for patent licenses, the Platform may deter innovation by reducing the economic reward for it. ${ }^{186}$ If an innovator knows that patents it contributes will be squeezed into an MCR rate, the innovator will stand to gain little for its improvements. The MCR provision will serve to undercut the reward even for improvement patents that are not "essential" and therefore do not fall within the Platform's scope. For financial reasons, potential licensees may choose to stick with the severely discounted MCR rate for the old patent rather than adopt innovations. Consequently, improvers will not be able to command very high royalty rates. The Commission properly noticed that the Platform may prove anticompetitive in this regard, because the MCR provision will reduce the incentive among $3 \mathrm{G}$ wireless communications companies to improve quality through innovation. However, the Commission was apparently persuaded to take a wait-and-see approach, perhaps only because other benefits of the Platform outweighed the potential harm done by limiting the incentive for innovation. ${ }^{187}$

However, in considering this issue, the Commission missed an opportunity to instruct the Platform's drafters to add another procompetitive feature to the agreement. To remedy the potential hindrance to innovation, the Commission could have compelled the Platform to incorporate a clause that would knock an essential patent out of the pool if an innovator devised an improvement over that essential patent. In this way, the improvement and the formerly essential patent could compete for the license fees of potential users. It is not certain whether this improvement clause would increase or decrease the fees that each would receive, but in either case the market would determine the fees. This market check would ensure that the cumulative royalty cap did not artificially restrict the innovator's economic incentive.

186. U.S. antitrust law is familiar with this practice. See Robert Patrick Merges \& John Fitzgerald Duffy, Patent Law and Policy 1398 (3d ed. 2002) (citing United States v. Automobile Mfrs. Ass'n, 307 F. Supp. 617 (C.D. Cal. 1969)); Intel Corp., Analysis to Aid Public Comment and Commissioner Statements, 64 Fed. Reg. 20134, 20135 (Apr. 23, 1999).

187. Nothing in the Commission's report explains the rationale for not challenging the Platform on the basis of deterring innovation. The Commission's entire pronouncement on the matter was that "licensing arrangements should not discourage further R\&D and innovation in the mobile communications sector." European Commission, supra note 15 , at 2 . Even the DOJ, in its significantly longer public pronouncement on the Platform, did not discuss this issuc. See Letter from Charles A. James, supra note 15 . It is possible that the Commission simply concluded that any restraint on innovation would not be effective in practice. 


\section{Conclusion: Approval of the Platform Was Justified Under European Community Law}

The features of the Platform render it generally suitable for implementation in Europe, in part because it is more likely to maintain competition than to thwart it. Although the potential for price fixing and reduced incentive for technological improvement raise antitrust concerns, the agreement's other features seem highly procompetitive. The transactional efficiencies of the clearinghouse licensing structure are undeniable. The Platform will also go a long way toward solving a potentially tremendous blocking-patents problem by facilitating market entry by many manufacturers, whether they possess essential patents or not. These features should help to ensure that $3 \mathrm{G}$ technology reaches consumers rapidly and that the market contains a number of competing providers. The MCR provision will probably even reduce consumer prices to some extent, although the precise scope of the provision's effect is uncertain.

Having completed the analysis of what the Commission did do, Part IV turns to a problem that the Commission did not, and possibly could not in the context of assessing a licensing agreement, seek to remedy.

\section{IV}

\section{The Remaining Problem of Separate Standard-Setting}

\section{AND LiCENSING ORGaNIZATIONS}

The Platform has survived the European Community's antitrust scrutiny, albeit with a number of conditions imposed. However, the separation of the patent-licensing organization from the standard-setting body still creates problems. This Section of the Comment inquires whether European competition law has created a catch-22: by discouraging unification of the standard-setting and licensing organizations, the law may actually promote monopolization.

Separating the intellectual property governance organization (the Platform) from standard-setting organizations (for example, the ITU and ETSI) limits the licensing body's ability to prevent capture. Any entity that wants to attempt to capture the standard and reap massive royalties from it may simply join the standard-setting organization but decline to join the Platform. In such a case, the standard-setting organization is defenseless if its intellectual property policy merely requires "reasonable efforts" to disclose patents relevant to the standard and lacks any mandatory licensing regime, as is the case with many standard-setting organizations. A strategic patent owner whose patented technology was about to be included in the standard could claim that it has made reasonable efforts to find patents related to the standard in its patent portfolio, while actually concealing that patent from the standard-setting body. It could then decline to join a separate patent pool like the Platform. At that point, the patent owner would be 
in position to demand royalties unlimited by the pool. Because of this danger, the Platform fails as a defense against capture. And because capturc obviously decreases competition, this factor should have weighed against European Commission approval of the Platform. ${ }^{188}$

Strategic intellectual property owners can exploit the divided system more effectively than they could a standard-setting organization with its own strong licensing policy. This argument begins from the premise that an innovator in the field would undoubtedly want to participate in the standard-setting organization so that it could keep abreast of developments, give technical advicc, and encourage the organization to adopt a standard that incorporates the innovator's patents. If the licensing policy is a condition of membership in the standard-setting organization, then most firms can be induced to suffer the "stick" of being forced to grant licenses cheaply in exchangc for the "carrot" of standard-setting organization membership and influence. But separating standard setting from licensing disengages the carrot from the stick. Under the disengaged model, the one or two biggest owners of essential patents will probably prefer to remain outside the patent pool. ${ }^{189} \mathrm{~A}$ firm that is heavily focused on licensing and not manufacturing would find this approach particularly beneficial. ${ }^{190}$ The licensing rules lose much of their power when they are separated from the standard-setting process.

The Commission itself may be partly to blame for this state of affairs. When it cracked down on the ETSI's licensing-by-default policy in the early 1990s, it may have led standard-setting organizations to believe that strong licensing policies would violate antitrust laws. ${ }^{191}$ The $3 \mathrm{G}$ case is distinct, however. Because the ETSI is a quasi-governmental organization, its standards essentially can be given the force of law. ${ }^{192}$ When the standardsetting body can promulgate compulsory standards and then require (in some circumstances) licensing of the patents implicated therein, the whole regime degenerates into a de facto compulsory licensing program. ${ }^{193} \mathrm{By}$ contrast, when a liccnse is merely compelled by a private bargain the patentee made, the situation raises fewer concerns about state interference with the market. Because of this key distinction, the ETSI's experience

188. The Platform does have some redeeming features that lessen, to a degree, the incentive for capture. First, by limiting royalties through the MCR clause, the provisions reduce the financial incentive to have one's patents included in the standard, so the incentive to capture is lessened. Second, by placing the determination of which patents are essential in the hands of a neutral arbiter, the Platform eliminates patent owners' brazen characterization of many of their patents as essential in an effort to trick manufacturers into purchasing unnecessary licenses. This practice has been a significant problem in the $2 \mathrm{G}$ market.

189. Unsurprisingly, this exact occurrence has befallen 3G. See supra note 166 .

190. See supra notes 81-85 and accompanying text.

191. See supra notes $45-53$ and accompanying text.

192. Bekkers \& Liotard, supra note 2, at 115.

193. Id. 
should not intimidate wholly private standard-setting bodies into adopting weak licensing rules.

Reuniting the standard-setting organizations with the patent-licensing organizations is not the only solution to this problem. A level of coordination between licensing and standard-setting bodies that presently seems to be lacking in the $3 \mathrm{G}$ case would suffice. If the ITU, for example, put off deciding on a particular standard until all the likely holders of essential patents had accepted or rejected the Platform, it might be able to adjust its choice of standards to avoid holdout firms' patents. ${ }^{194}$ This approach would preserve the useful structure that has been designed for the Platform, but would still link the licensing and standard-setting processes securely enough to greatly diminish the chances of capture and the resulting decrease in competition.

\section{CONCLUSION}

Regardless of the standards chosen, 3G mobile communications technology will be a complex jumble of intellectual property rights. Because of the standard-setting organizations' failure to establish effectual licensing policies, an independent licensing body will have to perform this role. The 3G Partnership Project has created the 3G Patent Platform in an effort to establish licensing policies, and, at least to the extent important licensors choose to participate in it, the agreement will serve as the final licensing authority for mobile communications standards.

The Platform has now received approval from all three of the world's leading antitrust authorities: Japan, Europe, and the United States. No doubt this has occurred because the Platform, on balance, promotes competition by at least partially untangling $3 \mathrm{G}$ patents and by providing a neutral arbiter to prevent fraudulent or biased characterization of patents as essential. The European Commission, however, might have done better to purge the Platform of its potential hindrance to improvement of $3 \mathrm{G}$ products by requiring a clause that would force substitutable patents to compete fully with each other. Such a modification would have improved the Platform's suitability for promoting the development of a competitive $3 \mathrm{G}$ communications market in Europe.

However, the Platform almost certainly will not work as well as its backers have hoped. ${ }^{195}$ The separation of the licensing and standard-setting organizations creates an extra degree of freedom that strategic intellectual

194. Clearly it has not taken this approach thus far. The ITU has approved, as one 3G standard, CDMA2000 1xEV-DO, which is used in Monet Mobile's new American 3G services. Qualcomm's patents dominate CDMA technology. Thus, demand for Qualcomm's technology is proving strong cnough to vindicate the company's strategy of bilateral licensing, at least at this early stage. Press Release, 3G, 3G CDMA2000 lxEV-DO Launched in US (Oct. 30, 2002), at http://www.3g.co.uk/ PR/October2002/432l.htm.

195. Cataldo, supra note 82 , at $\mathrm{l}$. 
property owners will almost certainly exploit. At present, the various standard-setting organizations do not compel members to participate in the Platform's licensing scheme, ${ }^{196}$ and there is no indication that these organizations plan to wait to see who commits to the Platform before deciding on standards. Thus, they may proceed with the urgent business of defining standards (to a significant extent, they have done so already ${ }^{197}$ ), but at the risk of standard capture by firms that see an advantage in staying out of the patent pool. If the standard-setting organizations are serious about eliminating capture, they should either imbue their standards-adoption process with knowledge of who is in and who is out of the Platform, or simply strengthen their own licensing requirements. And, if the European Commission is serious about preventing capture, it should clarify that it would not oppose such an arrangement.

196. 3GPP Agreement, supra note 59, art. 3.1 ("The Organizational Partners shall ... encourage their members to declare at the earliest opportunity any Intellectual Property Rights which they may have and believe to be essential, or potentially essential, to any ongoing work within 3GPP ...."); ETSI, Guide to European Competition Law, at http://www.etsi.org/legal/comp_law.htm (last visited Sept. 4, 2003) (stating merely that "members of a technical body [should bel encouraged to disclose the intellectual property rights . . . whieh their company may own and which might be or become Essential for the document being discussed"); American National Standards Institute, ANSI Essential Requirements: Due process requirements for American National Standards, art. 3.1.1 (Jan. 2003), available at http://public.ansi.org/ansionline/Documents/Standards\%20Activities/American\% 20National\%20Standards/Procedures,\%20Guides,\%20and\%20Forms (compelling members to commit to reasonable licensing of essential patents but lacking a strong mechanism like that in the $3 \mathrm{G}$ Patent Platform for the discovery and valuation of such patents).

197. "Fortunately, the 3G technical work at the ITU has already been done. This work will be remembered as perhaps the most difficult challenge to address in the deployment of $3 \mathrm{G}$ services because of the competing commercial intercsts involved.... The specifications contained in the standard, dubbed lMT-2000, will actually describe five distinct radio interfaces." Europe Prepares for $3 G$, PulseONLINE (Mar. 2000), at 13, at http://pulse.tiaonline.org/article.cfm?1D=405. 
